\title{
MOLDOVA'S WINES IN THE CONTEXT OF CLIMATE CHANGE
}

\author{
Ioana, REBENCIUC ${ }^{1}$, Ovidiu, TIȚA ${ }^{2 *}$ \\ "'Stefan cel Mare" University of Suceava, 13 University Street, Suceava, Romania \\ 2"Lucian Blaga" University of Sibiu, 10 Victoriei Boulevard, Sibiu, Romania \\ *corresponding author: ovidiu.tita@ulbsibiu.ro
}

\begin{abstract}
The aims of this work is to characterize the physico-chemical characteristics of grape varieties and wines from the wine region of Moldova under current climate change conditions. The musts from the varieties Busuioaca de Bohotin, Fetească neagră, Muscat Ottonel and Pinot gris showed values of sugars between $198 \mathrm{~g} / \mathrm{L}$ and $254 \mathrm{~g} / \mathrm{L}$, acidity $5.04 \mathrm{~g} / \mathrm{L} \mathrm{H}_{2} \mathrm{SO}_{4}$ and $7.92 \mathrm{~g} / \mathrm{L}$ $\mathrm{H} 2 \mathrm{SO} 4$, the total nitrogen was between $0.91 \mathrm{~g} / \mathrm{L}$ and $1.54 \mathrm{~g} / \mathrm{L}$. The wines obtained were characterized by alcohol concentration and sulfur dioxide with values falling within standards, total acidity on average lower than the musts with one unit, and the dry nonreducing extract ranged from $22.1 \mathrm{~g} / \mathrm{L}$ to $32,4 \mathrm{~g} / \mathrm{L}$. It has been found that climate change, especially rising temperatures, leads to an accumulation of sugars and extract in musts and wines from the Moldova Vineyards.
\end{abstract}

KEY WORDS: climate change, musts, physical-chemical analisys, wines

\section{INTRODUCTION}

The grape varieties in our country have undergone a series of changes in their morpho-chemical structure over time, due to evolutionary, climatic or under the influence of the cultivator. Specialists in the field are constantly looking for those varieties with resistance to pests, high yield in processing or those with higher aromatic potential. The wine-growing potential of many regions is constantly changing due to the climatic changes that have occurred in the last period and adapting the different varieties is a challenge for the specialists (Costea et al. 2019). Studies show that in recent years the climatic data collected in the wine regions of our country have undergone relevant changes, changes with a major impact on the wine and the quality of the varieties. Thus, in 2018, Irimia and her colleagues published a study that analyzes the average daily temperatures, precipitation and amplitude of the solar rays over a period of 52 years, with data taken from about 150 weather stations in Romania. The correlation between climate and wine production was expressed by the oenoclimate aptitude index (IAOe), which integrates the influence of temperature, sun duration and precipitation on wines. The results of this study reveal an extension of the climate zone suitable for wine production in Romania; also it was found that due to the climatic factors the wines can be cultivated at higher altitudes, specifying that these changes favor the cultivation of mainly red soils (Tonietto et al. 2004, Bojariu et al. 2015, Irimia et al. 2018). The study allows an in-depth analysis from a spatial perspective of the changes caused by climate change in the wine-growing areas, constituting a solid support for the development of the strategies of adaptation of the viticulture to the new climatic context (Irimia et al. 2018, Cichi 2006)

The climatic fit for the wine production determines the possibility of growing the wines, the assortments of grape varieties in the wine regions and their types of wine. Climate suitability is a stable feature of a wine-growing area over time, with slight variations from year to year, and yet unable to modify the specific type of wine production in a wine-growing region. In the context of climate change, this feature of the wine regions changes significantly, which leads to important consequences: changes in the phenology of wines, early maturation of grapes, higher alcoholic potential and lower total acidity of grape must, color changes appear and aromatic and sensory profile of wines (Irimia et al. 2014, Irimia et al. 2015, Jones et al. 2005, Vișan et al. 2017, Sadras et al. 2013).

Changing the climate suitability for wine production is manifesting globally, with harmful consequences in the warmer Mediterranean areas and positive consequences for the northern wine regions with a colder climate, which can diversify their wine types. Projections based on climate models predict the extension of the area suitable for growing wines beyond the northern and southern limits of the wine-growing surface globally, as well as the transition to higher altitudes (Irimia et al. 2018, Irimia et al. 2017).

The Moldova area is mainly sought after because of the high quality grapes, which can lead to obtaining elite wines, the potential wine-viticulture of the area being well known. An increasingly important segment of the population focuses on the consumption of aromatic or semi-aromatic wines, red or rosé, their share exceeding by $25 \%$ the consumption of the $90 \mathrm{~s}$. The pedo-climatic indicators, the area of origin are usually an important factor of selection and discrimination of the varieties, their value being reflected in the quality of the wines obtained (Cotea et al. 2008, Hidalgo Togores 2003, Burzo 2014, Lengyel 2012). The wines from this area have characteristics described in specialized studies (Bichescu et al. 2018, Coarfă et al. 2018) focusing in particular on aromatic, sensory, but also physicochemical characters (Duchene et al. 2005, Lengyel 2015, Rotaru et al. 2013, Tartian et al. 2015).

\section{MATERIALES AND METHODES}

- grapes from the varieties Busuioaca de Bohotin, Fetească neagră, Muscat Ottonel, Pinot gris, harvests of the years 2016, 2017, 2018, from the vineyards: Bohotin, Cotești, Cotnari, Huşi and Iași, selected and pressed in must (the varieties were noted with acronyms: Busuioaca de Bohotin: BB, Feteasca neagră: FN, Muscat Ottonel: MO, Pinot gris: PG)

- in the characterization of these grape varieties was followed:

- sugar concentration (g/L)

- the concentration of titratable organic acids ( $\mathrm{g} / \mathrm{L}$ sulfuric acid) 
- concentration of nitrogenous substances: total nitrogen (mg / L)

- wines obtained from the varieties Busuioaca de Bohotin, Fetească neagră, Muscat Ottonel, Pinot gris, harvests of 2016, 2017, 2018, from the vineyards: Bohotin, Cotești, Cotnari, Huși and Iași. The wines were obtained by the classic technology, specific to the selected vineyard (DOC Specification)

- for the characterization of these wines the following analyzes were performed:

- determination of alcohol concentration (\% vol)

-determining the reducing sugar $(\mathrm{g} / \mathrm{L})$

- determination of total acidity ( $\mathrm{g} / \mathrm{L}$ sulfuric acid)

-determining the non-reducing dry extract (g/L)

The working methods were those accredited by the International Wine Organization (OIV) in the field

(http://www.oiv.int/en/technical-standards-anddocuments/methods-of-analysis/compendium-of-internationalmethods-of-analysis-of-wines-and-musts)

\section{RESULTS AND DISCUSSIONS}

\subsection{Physico-chemical qualities of musts}

The accumulation of sugars in grapes (Figure 1) usually takes place at full maturity, when they have reached maximum weight, overmaturation being indicated rather for the selected wines, chosen, where the quality prevails in front of the quantity. In the five vineyards selected the grapes were harvested at the beginning of september, when the method of 200 grains per 200 buds showed that this is recommended. The calculated bioclimatic indices, especially the Oeclimatic Aptitude, have been ascending since 2016, being specific in each vineyard. There are higher values in the Huși, Iași and Cotnari vineyards where they exceed 4800 compared to the Bohotin Vineyard, Cotești where they are located between 3800-4300. Thus, it was observed that in 2016 the Busuioaca de Bohotin variety presented a maximum concentration of $238 \mathrm{~g} / \mathrm{L}$ sugars, in Iași vineyard, followed by Huși with $231 \mathrm{~g} / \mathrm{L}$, and the lowest values were registered in Bohotin and Cotești Vineyards with $223 \mathrm{~g} / \mathrm{L}$. Feteasca neagră variety has accumulated a maximum of $225 \mathrm{~g} / \mathrm{L}$ sugars in Iasi Vineyard, and a minimum of $198 \mathrm{~g} / \mathrm{L}$ in Cotești Vineyard. The Muscat Ottonel variety was noted with a remarkable accumulation in the Huși Vineyard, with $239 \mathrm{~g} / \mathrm{L}$, followed by Iasi with $236 \mathrm{~g} / \mathrm{L}$, Bohotin with $234 \mathrm{~g} / \mathrm{L}$, and the lowest value was recorded at Cotnari of $222 \mathrm{~g} / \mathrm{L}$. As for the grapes from the Pinot gris variety, they presented close values in three vineyards, namely: Bohotin, 232 g/L, Coteşti and Iaşi 233 $\mathrm{g} / \mathrm{L}$, the maximum level being identified in the case of Cotnari Vineyard.

The year 2017 was noted by a slight warming, the values of the sugars ranging from one vineyard to another. For the Busuioaca de Bohotin variety, the acetate ranged between $213 \mathrm{~g} / \mathrm{L}$ in Cotești Vineyard and $237 \mathrm{~g} / \mathrm{L}$ in Huși. Intermediate values showed the Bohotin Vineyard with $223 \mathrm{~g} / \mathrm{L}$, Cotnari with 221 $\mathrm{g} / \mathrm{L}$ and Iași with $232 \mathrm{~g} / \mathrm{L}$. The grapes from the Feteasca neagra variety were noted by sugar accumulations at concentrations of $203 \mathrm{~g} / \mathrm{L}$ at Cotnari, $204 \mathrm{~g} / \mathrm{L}$ at Cotești and a maximum of 221 $\mathrm{g} / \mathrm{L}$ at Iasi, $220 \mathrm{~g} / \mathrm{L}$ at Bohotin and $217 \mathrm{~g} / \mathrm{L}$ to Huşi. Muscat Ottonel variety accumulates in the same period sugars reaching $242 \mathrm{~g} / \mathrm{L}$ at Iași Vineyard, followed by Bohotin with $234 \mathrm{~g} / \mathrm{L}$, Cotești and Huși with $228 \mathrm{~g} / \mathrm{L}$ and $229 \mathrm{~g} / \mathrm{L}$ respectively, and the lowest value was noted in Cotnari Vineyard with $218 \mathrm{~g} / \mathrm{L}$. In the same year the Pinot gris variety shows variations in the accumulation of sugars starting from $224 \mathrm{~g} / \mathrm{L}$ in the Bohotin Vineyard and reaches a value of $239 \mathrm{~g} / \mathrm{L}$ in the Iasi Vineyard. In Huşi and Cotești Vineyards, sugars accumulated in concentrations of $236 \mathrm{~g} / \mathrm{L}$ respectively $237 \mathrm{~g} / \mathrm{L}$, and in Cotnari the values did not exceed $231 \mathrm{~g} / \mathrm{L}$. In the year 2018 , overall values of sugar in all these vineyards are noted, ranging from $222 \mathrm{~g} / \mathrm{L}$ to $254 \mathrm{~g} / \mathrm{L}$. Thus, it is observed that the Busuioaca de Bohotin variety has sugar concentrations that are at a minimum of $229 \mathrm{~g} / \mathrm{L}$ in Cotnari and a maximum of $248 \mathrm{~g} / \mathrm{L}$ in Bohotin and Huşi. Values of $247 \mathrm{~g} / \mathrm{L}$ were highlighted in the case of Iași Vineyard and $232 \mathrm{~g} / \mathrm{L}$ in the case of Cotești. The values of sugars identified in the case of the Feteasca neagra variety start from $212 \mathrm{~g} / \mathrm{L}$ in Iasi and a maximum of $239 \mathrm{~g} / \mathrm{L}$ in Huși, followed by the Cotnari Vineyard where they reach $238 \mathrm{~g} / \mathrm{L}$. The Bohotin and Cotești Vineyards stand out for this variety with values of $229 \mathrm{~g} / \mathrm{L}$ respectively $227 \mathrm{~g} / \mathrm{L}$. Muscat Ottonel variety accumulates the most significant amount of sugars, namely 254 $\mathrm{g} / \mathrm{L}$ in the Bohotin Vineyard followed by Iasi with $247 \mathrm{~g} / \mathrm{L}$, Huşi with $238 \mathrm{~g} / \mathrm{L}$. Slightly lower values are observed in the case of Cotești and Cotnari Vineyards with $222 \mathrm{~g} / \mathrm{L}$ and $224 \mathrm{~g} / \mathrm{L}$ respectively. The Pinot gris variety accumulates considerably more sugars so that it reaches a value of $247 \mathrm{~g} / \mathrm{L}$ in the Huși Vineyard, $242 \mathrm{~g} / \mathrm{L}$ in the Bohotin Vineyard and $240 \mathrm{~g} / \mathrm{L}$ in the Iasi Vineyard. Lower values are found in Cotnari and Cotești where they do not exceed $231 \mathrm{~g} / \mathrm{L}$ respectively $221 \mathrm{~g} / \mathrm{L}$.

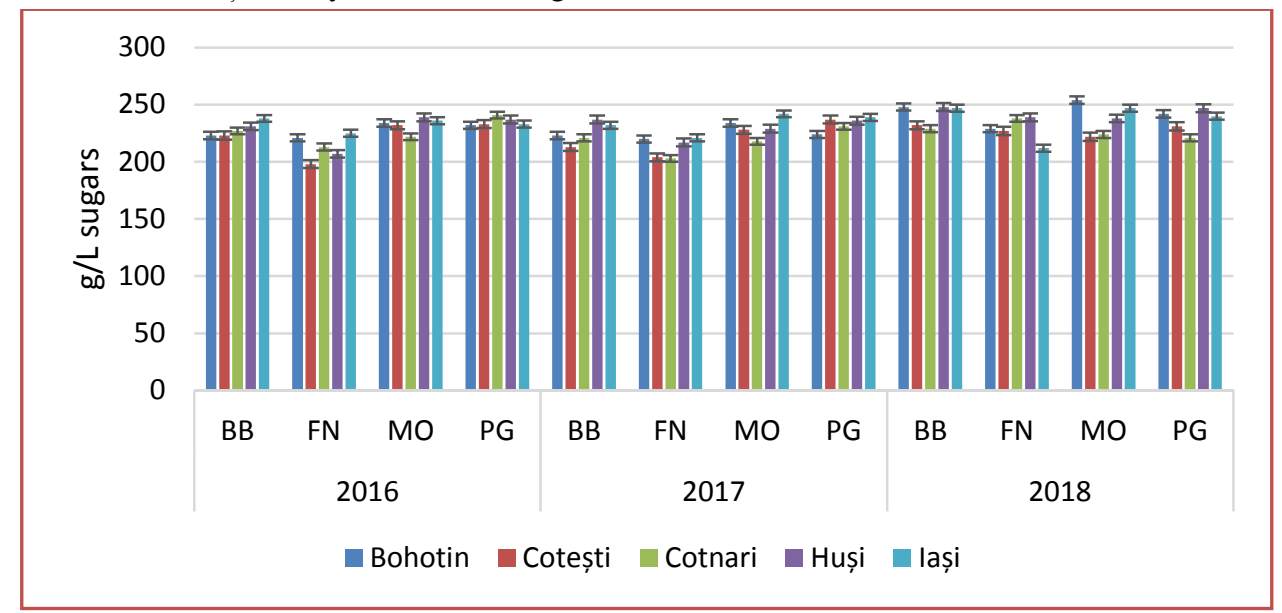

Figure 1. The concentration of sugars in the four varieties of musts from Busuioaca de Bohotin, Feteasca neagră, Muscat Ottonel, Pinot gris grapes, harvests of 2016, 2017, 2018, from the Bohotin, Cotești, Cotnari, Huşi and Iași vineyards 
The total acidity was expressed in sulfuric acid $\left(\mathrm{H}_{2} \mathrm{SO}_{4}\right)$ and in the worked musts has values between $5.04 \mathrm{~g} / \mathrm{L}$ and $7.92 \mathrm{~g} / \mathrm{L}$ . In figure 2 it is noted that the acids in the must have specific variations of each variety and what is more relevant is that the values decrease slightly in years, which confirms climate change, in the sense that an increase of the average annual temperatures is noticed, namely from $9.1^{\circ} \mathrm{C}$ in 2016 at Cotnari to $9.8^{\circ} \mathrm{C}$ in 2018 in Iași. Busuioaca de Bohotin variety was noted in 2016 with values of organic acids ranging from $5.27 \mathrm{~g} / \mathrm{L}$, $5.43 \mathrm{~g} / \mathrm{L}$ to Bohotin and 7.31 g / L in Huşi, $7.23 \mathrm{~g} / \mathrm{L}$ in Cotești and 6.18 in Iași. The Fetescă neagră variety has values that exceed $6 \mathrm{~g} / \mathrm{L}$ in Cotești and Huși and reach $7.13 \mathrm{~g} / \mathrm{L}$, in Cotnari and $7.21 \mathrm{~g} / \mathrm{L}$ in Bohotin. As for Muscat Ottonel, the values of organic acids are located in quantities ranging from $5.16 \mathrm{~g} / \mathrm{L}$ in Iasi vineyard and reach $7.92 \mathrm{~g} / \mathrm{L}$ in Cotnari, while the variety Pinot gris starts from values of $5.07 \mathrm{~g} / \mathrm{L}$ at Huşi and reaches $7.91 \mathrm{~g} / \mathrm{L}$ at Cotnari vineyard. In 2017, slightly lower values are observed compared to the previous one, culminating with the year 2018, when organic acids have lower amounts on average by $8 \%$ compared to 2016 . Thus, the Busuioaca de Bohotin variety oscillates around $7 \mathrm{~g} / \mathrm{L}$, for the Bohotin, Huşi and Iași vineyards and slightly over $5 \mathrm{~g} / \mathrm{L}$ for the Cotești and Cotnari vineyards. The black Fetescă variety has values ranging from $5.04 \mathrm{~g} / \mathrm{L}$ in Cotești and $7.20 \mathrm{~g} / \mathrm{L}$ in Bohotin, with intermediate values for the other three vineyards. The lowest determined values are noted in the case of the Muscat Ottonel variety, these being between $5.08 \mathrm{~g} / \mathrm{L}$ in Cotnari and $6.29 \mathrm{~g} / \mathrm{L}$ in Iași, while the variety Pinot gris has amounts of $5.32 \mathrm{~g} / \mathrm{L}$ in Huși and a maximum of $7.39 \mathrm{~g} / \mathrm{L}$ in Iaşi and Cotești. The year 2018 presents lower values of organic acids in grape must, rising temperatures leading to this. The Busuioaca de Bohotin variety has values between $5.11 \mathrm{~g} / \mathrm{L}$ in Huși, $5.19 \mathrm{~g} / \mathrm{L}$ in Cotnari, 5.32 $\mathrm{g} / \mathrm{L}$ in Cotești, $6.15 \mathrm{~g} / \mathrm{L}$ in Iasi and a maximum to $6.48 \mathrm{~g} / \mathrm{L}$ from Bohotin.

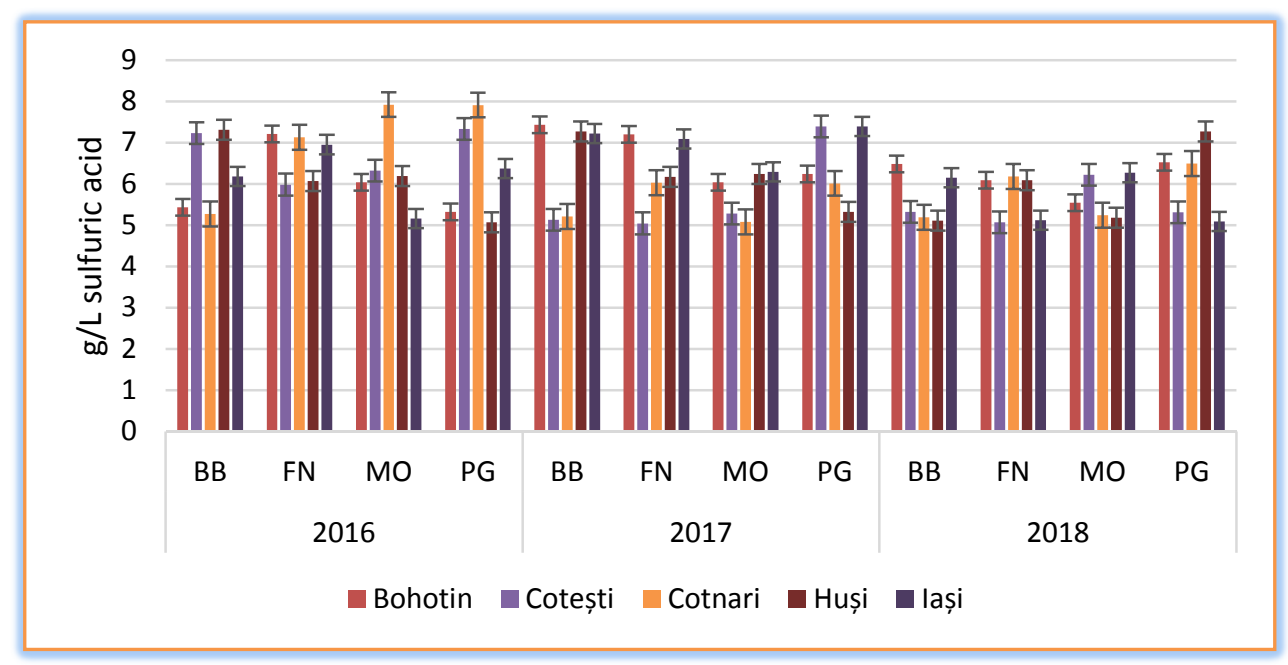

Figure 2. Concentration of titrable organic acids (total acidity) in the four varieties of musts from Busuioaca de Bohotin, Feteasca neagră, Muscat Ottonel, Pinot gris grapes, harvests of the years 2016, 2017, 2018, from the Bohotin, Cotești, Cotnari, Huși and Iași vineyards expressed in gram sulfuric acid / $\mathrm{L}$

Significantly close to the values of the Feteasca neagră variety, where the organic acids were between $5.07 \mathrm{~g} / \mathrm{L}$ in Cotești and $6.18 \mathrm{~g} / \mathrm{L}$ in Cotnari. Intermediate values were determined in Iasi of $5.12 \mathrm{~g} / \mathrm{L}$ and in Bohotin and Huşi of $6.09 \mathrm{~g} / \mathrm{L}$. In the same descending line were presented the varieties Muscat Ottonel and Pinot gris, with the exception of the Huși Vineyard, where the variety Pinot gris accumulated $7.27 \mathrm{~g} / \mathrm{L}$.

The total nitrogen values (Figure 3) were close in the three years of study, being between $0.91 \mathrm{~g} / \mathrm{L}$ and $1.52 \mathrm{~g} / \mathrm{L}$. In the Bohotin Vineyard the total nitrogen was at values between the three years between $1.04 \mathrm{~g} / \mathrm{L}$ in the case of Muscat Ottonel must in 2017 and $1.54 \mathrm{~g} / \mathrm{L}$ in 2018 for the same variety. In the Coteşti vineyard, the determined values were between $1.04 \mathrm{~g} / \mathrm{L}$ for the black Feteasca variety in 2017 and $1.39 \mathrm{~g} / \mathrm{L}$ for the Pinot gris variety the same year.

In the case of Cotnari vineyard, the total nitrogen is at lower values on average by $5 \%$ compared to the Cotești Vineyard, these oscillating around zone 1. At Huși the total nitrogen exceeds $1.07 \mathrm{~g} / \mathrm{L}$ in the case of Pinot gris variety in 2016, reaching value maximum in 2017 of $1.32 \mathrm{~g} / \mathrm{L}$.

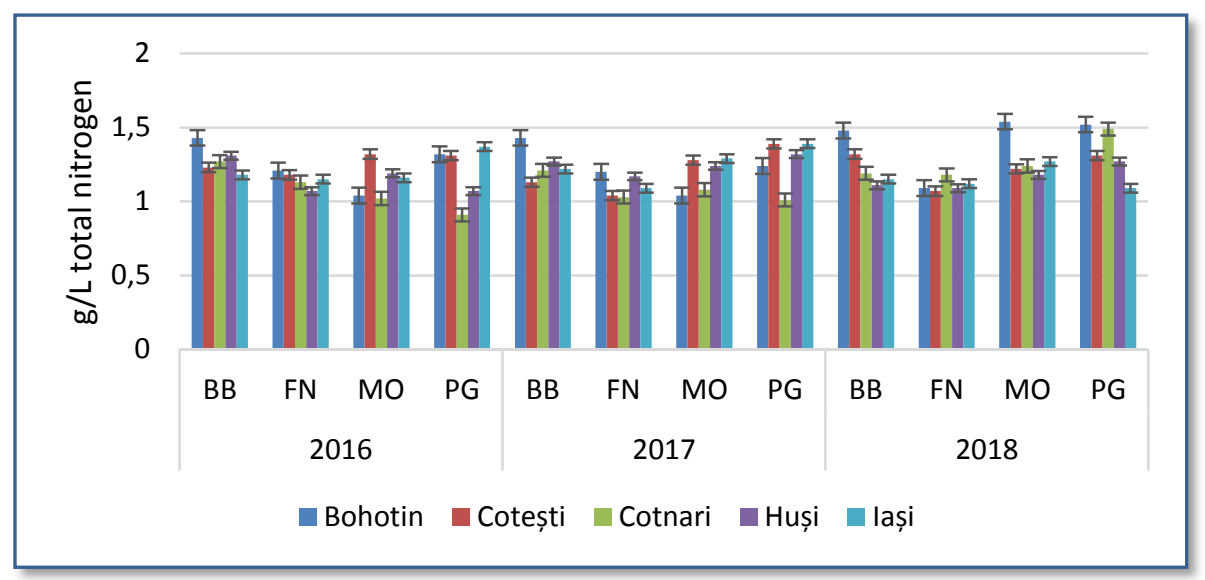


Figure 3. Concentration of total nitrogen in the four varieties of musts from Busuioaca de Bohotin, Feteasca neagră, Muscat Ottonel, Pinot gris grapes, harvests of the years 2016, 2017, 2018, from the Bohotin, Cotești, Cotnari, Huși and Iași vineyards

\subsection{Physico-chemical qualities of wines}

As can be seen in figure 4 , the wines from the grape varieties under study have slight variations in terms of alcohol concentration, falling within the permissible limits.

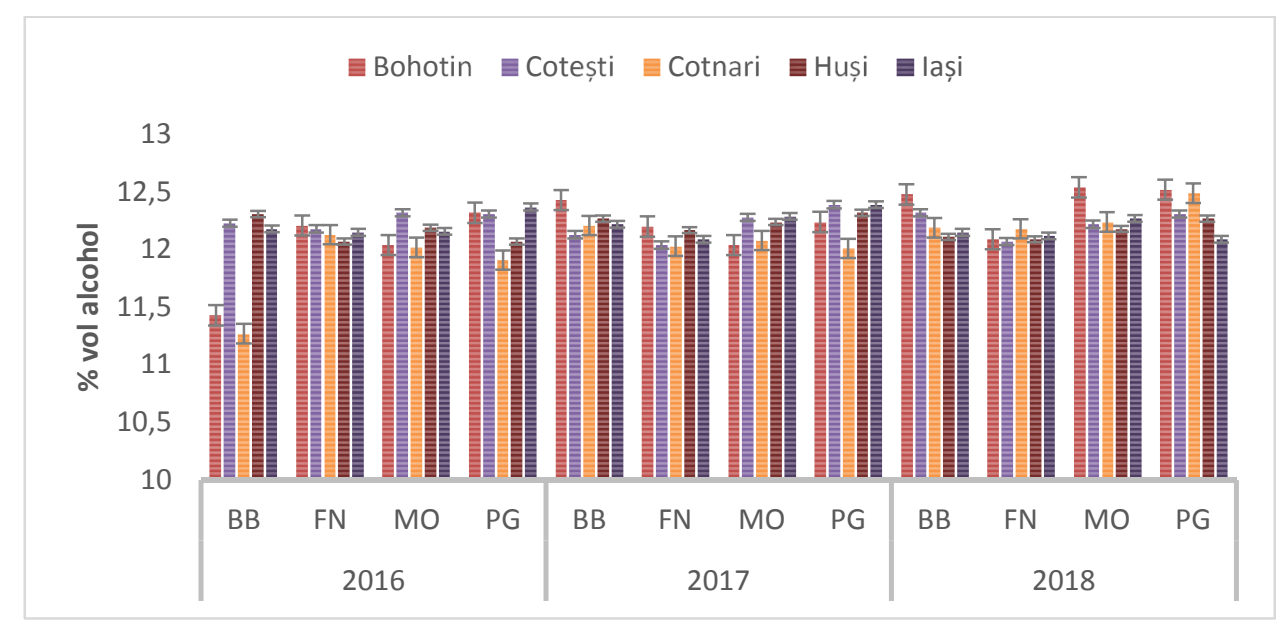

Figure 4. Concentration of alcohol in the four varieties of wine from Busuioaca de Bohotin, Feteasca neagră, Muscat Ottonel, Pinot gris grapes, harvests of the years 2016, 2017, 2018, from the Bohotin, Cotești, Cotnari, Huși and Iași vineyards

From the results data it is noted that in 2016 the Busuioaca de Bohotin wine has the lowest concentration of alcohol $11.27 \%$ vol in Cotnari and $11.43 \%$ vol in Bohotin, followed in the same year by Pinot gris wine in Cotnari $(11,91 \%$ vol.). In 2017 and 2018 the values of alcohols exceed $12 \%$ vol in all cases, ranging from $12.03 \%$ vol. in Cotnari (Feteasca neagră) and $12.54 \%$ vol. in Bohotin for Muscat Ottonel.

The titrable organic acids (total acidity) are noticeable by slightly lower values than the musts, being in 2016 between 4.46 $\mathrm{g} / \mathrm{L} \mathrm{H}_{2} \mathrm{SO}_{4}$ for the Busuiaca de Bohotin wine from Bohotin and $6.83 \mathrm{~g} / \mathrm{L} \mathrm{H}_{2} \mathrm{SO}_{4}$ for the same from the vineyard. Coteşti. For 2017, the obtained values were between $4.29 \mathrm{~g} / \mathrm{L} \mathrm{H}_{2} \mathrm{SO}_{4}$ and $6.33 \mathrm{~g} \mathrm{/} \mathrm{L} \mathrm{H}_{2} \mathrm{SO}_{4}$ for the Busuioaca variety of Bohotin from Cotnari and Bohotin. Intermediate values were obtained for the Black Feteas assortments of $4.44 \mathrm{~g} / \mathrm{L} \mathrm{H}_{2} \mathrm{SO}_{4}-6.20 \mathrm{~g} / \mathrm{L} \mathrm{H}_{2} \mathrm{SO}_{4}$ (Cotești / Bohotin), Muscat Ottonel $4.59 \mathrm{~g} / \mathrm{L} \mathrm{H}_{2} \mathrm{SO}_{4}-5.24 \mathrm{~g} / \mathrm{L}$ $\mathrm{H}_{2} \mathrm{SO}_{4}$ (Cotești /Huși) and Pinot gris $4.92 \mathrm{~g} / \mathrm{L} \mathrm{H}_{2} \mathrm{SO}_{4}-6.19 \mathrm{~g} /$ $\mathrm{L} \mathrm{H}_{2} \mathrm{SO}_{4}$ (Huși / Iași).

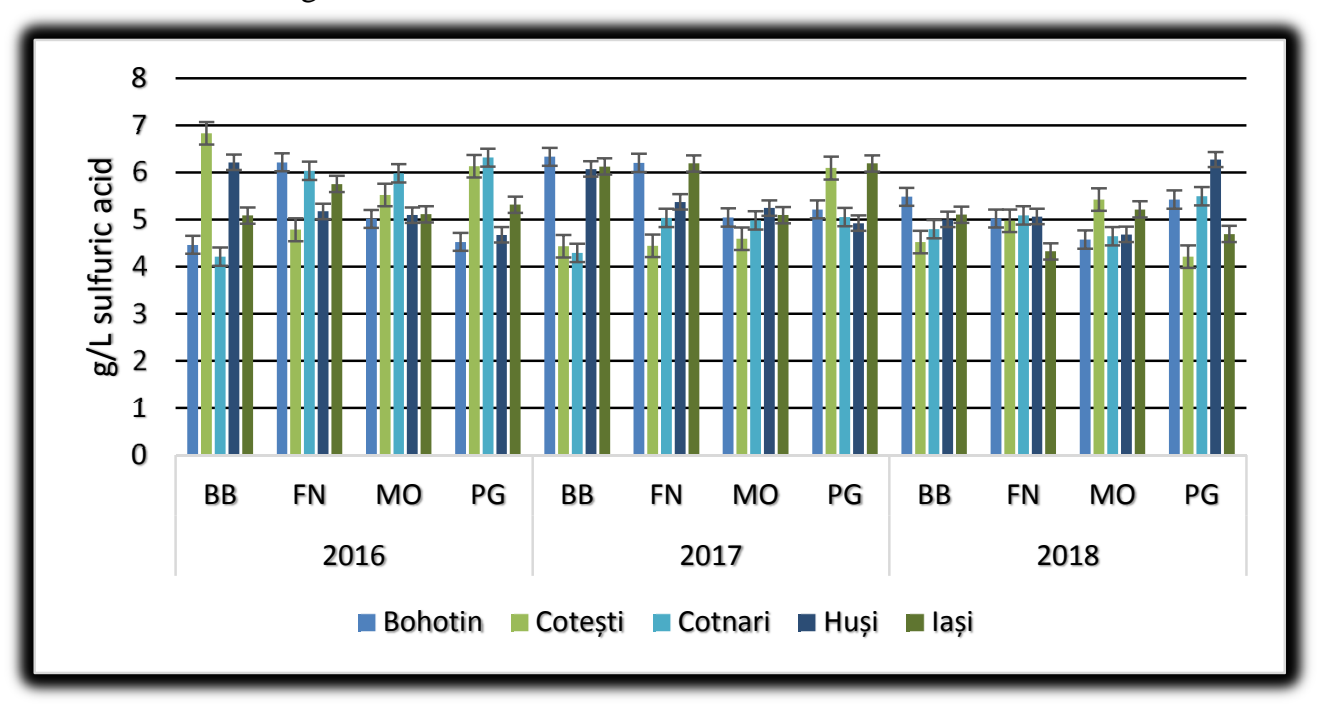

Figure 5. Concentration of the titrable organic acids (total acidity) in the four varieties of wine from Busuioaca de Bohotin, Feteasca neagră, Muscat Ottonel, Pinot gris grapes, harvests of the years 2016, 2017, 2018, from the Bohotin, Cotești, Cotnari, Huși and Iași vineyards exprimed în sulfuric acid

Figure 6 shows the concentration of sulfur dioxide identified in the wines selected during the three years of study. It is observed that the values do not show significant variations, the minimum identified in 2016 being $114.3 \mathrm{~g} / \mathrm{L}$ in Bohotin the Busuioaca range of Bohotin and a maximum of $141.1 \mathrm{~g} / \mathrm{L}$ in Cotnari, the Pinot gris assortment. 


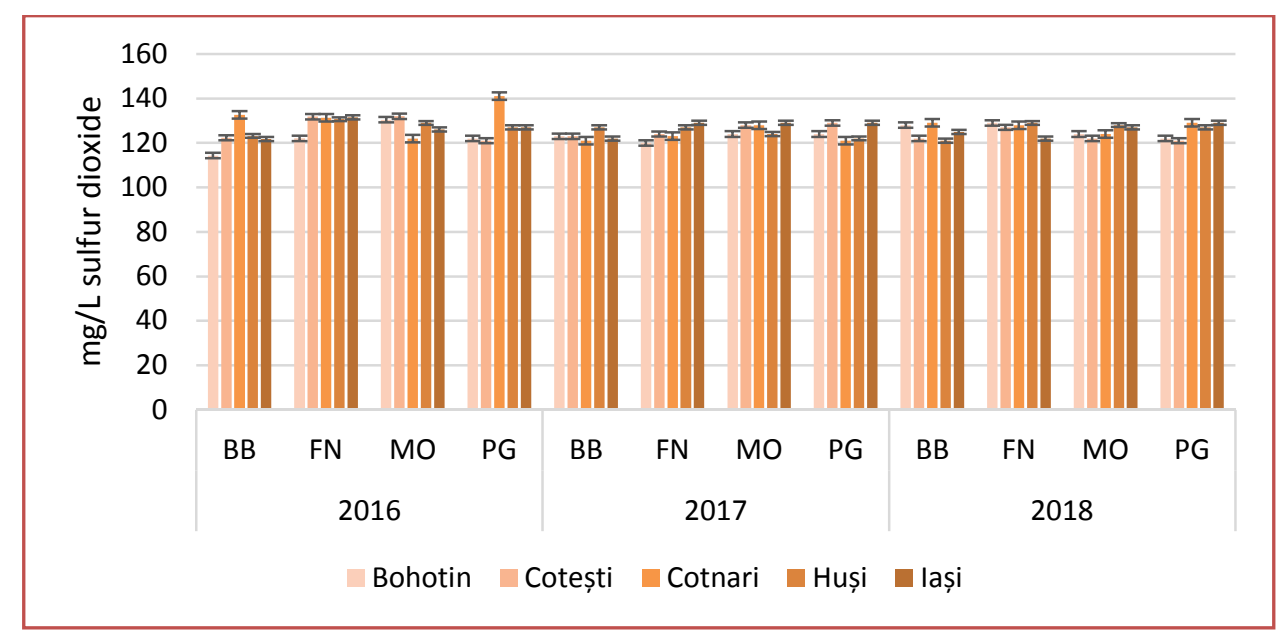

Figure 6. Concentration of sulfur dioxide in the four varieties of wine from Busuioaca de Bohotin, Feteasca neagră, Muscat Ottonel, Pinot gris grapes, harvests of the years 2016, 2017, 2018, from the Bohotin, Cotești, Cotnari, Huşi and Iași vineyards

Regarding the non-reducing dry extract, it gives valuable indications regarding the quality of the wine along with the alcoholic strength and the odorants (Figure 7). For the selected period, 2016-2018, the wines submitted to the study were noted by generous values of non-reducing dry extract. The hot and dry summers have contributed to the accumulation of elements that lead to this.

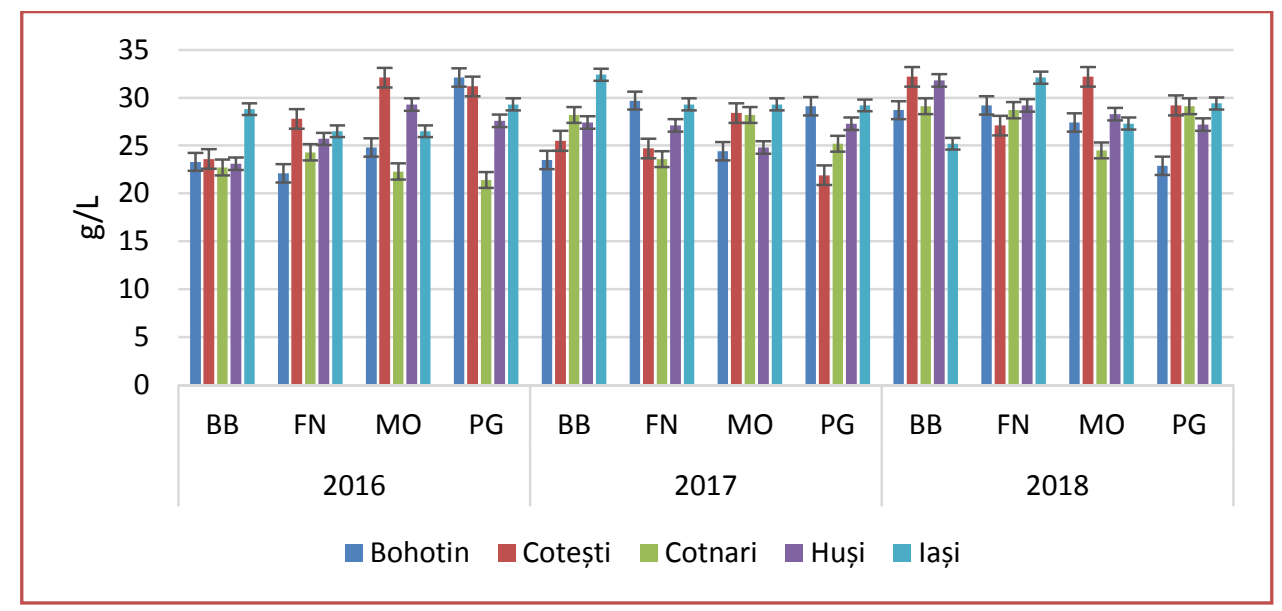

Figure 7. Concentration of non-reducing dry extract in the four varieties of wine from Busuioaca de Bohotin, Feteasca neagră, Muscat Ottonel, Pinot gris grapes, harvests of the years 2016, 2017, 2018, from the Bohotin, Cotești, Cotnari, Huşi and Iași vineyards

For 2016, the obtained values were at a minimum of $21.4 \mathrm{~g} / \mathrm{L}$ and a maximum of $32.1 \mathrm{~g} / \mathrm{L}$. For the Busuioaca de Bohotin assortment the values were between $22.7 \mathrm{~g} / \mathrm{L}$ at Cotnari Vineyard and a maximum of $28.8 \mathrm{~g} / \mathrm{L}$ at Iași Vineyard. Intermediate values were obtained at Bohotin $23.3 \mathrm{~g} / \mathrm{L}$, Cotești 23.6 g / L, Huși 23.1 g / L. For the Fetească neagră assortment, the non-reducing dry extract presented the following values: At Bohotin 22,1 g / L, with 19\% more at Cotești, $24.3 \mathrm{~g} / \mathrm{L}$ at Cotnari, and at Huși and Iași the values were at $25.7 \mathrm{~g} / \mathrm{L}$ respectively $26.5 \mathrm{~g} / \mathrm{L}$. The Muscat Ottonel assortment presents maximum values of $32.1 \mathrm{~g} / \mathrm{L}$ in Cotești and a minimum of 22.3 $\mathrm{g} / \mathrm{L}$ in Cotnari, while the Pinot gris assortment goes to extremes starting from $21.4 \mathrm{~g} / \mathrm{L}$ at Cotnari Vineyard and reaches the value of $32.1 \mathrm{~g} / \mathrm{L}$ at the Bohotin Vineyard. In 2017 there is an increase of the non-reducing dry extract compared to 2016 on average by $1.2 \%$, so that the minimums were at values of $21.9 \mathrm{~g}$ / $\mathrm{L}$ and the maximums at $32.4 \mathrm{~g} / \mathrm{L}$. Thus, the Busuioaca de Bohotin wine assortment ranges from $23.5 \mathrm{~g} / \mathrm{L}$ at Bohotin Vineyard and reaches $32.4 \mathrm{~g} / \mathrm{L}$ at Iaşi Vineyard. Feteasca neagra presents non-reducing dry extract values from $23.6 \mathrm{~g} / \mathrm{L}$ in Cotnari and reaches a maximum of $29.7 \mathrm{~g} / \mathrm{L}$ in Bohotin. For Muscat Ottonel wine this analysis leads to results starting from $24.4 \mathrm{~g} / \mathrm{L}$ in Bohotin and reaching $29.3 \mathrm{~g} / \mathrm{L}$ in Iasi, while Pinot gris presents a maximum of $29.2 \mathrm{~g} / \mathrm{L}$ in Iasi. The year 2018 brings significantly higher values to the entire range of selected wines, so the minimums start at $22.9 \mathrm{~g} / \mathrm{L}$ and reach $32.2 \mathrm{~g} / \mathrm{L}$. For all the vineyards the values of non-reducing dry extract this year exceed the value of $25.2 \mathrm{~g} / \mathrm{L}$ in the Busuioaca de Bohotin assortment, for the Feteasca neagra $27.1 \mathrm{~g} / \mathrm{L}$, for the Muscat Ottonel $27.3 \mathrm{~g} / \mathrm{L}$, and for the Pinot gris more modest $22.9 \mathrm{~g} /$ L. This year there is a $1.2 \%$ increase in the values determined by non-reducing dry extract compared to the previous year and $1.4 \%$ more than in 2016.

\section{CONCLUSIONS}

As noted in the determinations carried out the concentration of sugars is increasing since 2016, which is explained by the increase of temperatures during the summer, the decrease in volume of precipitation, in conclusion the main factors that contribute to their accumulation in grapes. The grapes selected for the study presented significant values of sugars, these competing for the quality of the wines obtained. The alcoholic strength of the resulting wines is satisfactory, it is within the quality norms established at the level of vineyards and both national and European legislation. The acidity of the must undergoes a slight decrease compared to other years, the pedoclimatic factors and the quality of the variety being decisive in this case, and the acidity of the wine gives freshness and flavor 
to them. Must nitrogen is one of the elements that help the yeasts to trigger and lead a balanced alcoholic fermentation, the values determined being optimal in this regard. The amount of sulfur dioxide resulting is not a negative element, the resulting values fall within the norms, so that the wines can be considered biologically stable.

The non-reducing dry extract is a valuable indicator of quality wines, observing an upward accumulation over the years, due to the pedo-climatic conditions, the heating of the climate, the reduction of precipitation but also the increase of the sun during this period. All these substances such as non-volatile acids, glycerol, pectic substances, polyphenols, gums, nitrogenous and mineral substances that define the non-reducing dry extract are concentrated in wine and give them fineness, softness, qualities that are found in Moldova wines.

\section{REFERENCES}

1. Bichescu C., Stanciu S., 2018, The sensory properties and chromatic characteristics of Fetească Neagră red wine after the treatment with gum arabic and alternative oak products, Romanian Biotechnological Letters Vol. 23, No. 4, 1379313803

2. Bojariu R., Bârsan V. M., Cică R., Velea L., Burcea S., Dumitrescu Al., 2015, Schimbările climatice - de la baze fizice la riscuri şi adaptare. Administraţia Naţională de Meteorologie (Printech Bucureşti, 2015)

3. Burzo I., 2014, Modificările climatice și efectele asupra plantelor horticole. Editura Sitech, 7 - 41

4. Cichi D. D., 2006, Modificările termice din ecosistemul viticol. (Cauze, efecte asupra viței de vie, studii). Editura Universitaria Craiova

5. Coarfă E., Popa M.E., 2018, Some relevant quality indicators of red wine from three grapes cultivars - a minireview, Scientific Bulletin. Series F. Biotechnologies, Vol. XXII, 70-80

6. Costea M., Lengyel E., Stegăruș D., Rusan N., Tăușan I., 2019, Assessment of climatic conditions as driving factors of wine aromatic compounds: a case study from Central Romania, Theoretical and Applied Climatology, 239-254

7. Cotea V.V., Rotaru L., Irimia L.M., Colibaba C., The effect of the total reheating on viticol ecoclimat in the northern zone of the Moldavia Romania, Conference: XXXI World Congress of Vine and Wine, At Verona, Italia, 2008

8. Duchêne E., Schneider C., 2005, Grapevine and climatic changes: A glance and the situation in Alsace. Agronomy for Suistainable Developement, 25, 93, 99

9. Hidalgo Togores, J., 2003, Tratado de enología (Vol. I and II). Madrid: Ediciones MundiPrensa
10. Irimia L.M., Patriche C.V., Quenol H, 2014, Analysis of viticultural potential and delineation of homogeneous viticultural zones in a temperate climate region of Romania, Int. Sci. Vigne Vin, 48, 145-167

11. Irimia L.M., Patriche C.V., Quenol H., Cotea V.V., 2015, Modificarea potențialului viticol al podgoriilor, ca efect al încălzirii climatului. Studiu de caz: Podgoria Cotnari. Hortus, Nr. 14, 187 - 192

12. Irimia L., Patriche C.V., Quenol H., Sfâcă L., Foss C., 2018, Shifts in climate suitability for wine production as a result of climate change in a temperate climate wine region of Romania. Theor Appl Climatol. Volume 131, Issue 3-4, pp 1069-1081

13. Irimia L.M., Patriche C.V., Roșca B., 2018, Climate change impact on climate suitability for wine production in Romania, Theor Appl Climatol., 133:1-14

14. Jones G.V., White M.A., Cooper O.R., Storchmann K., 2005, Climate change and global wine quality, Climatic Change, 73(3), 319 - 343

15. Lengyel E., 2012, Primary aromatic character of wines, Acta Universitatis Cibiniensis, Series E: Food Technology, ISSN 1221-4973, vol.XVI, (1), pp. 3-18

16. Lengyel E., 2015, Cercetări privind optimizarea proceselor fermentative în vederea păstrării și consolidării tipicității și autenticității vinurilor românești, Ed. Universităţii Lucian Blaga Sibiu

17. Rotaru L., Colibaba L. C., Prisăcaru A. I., 2013, Studies of the behavioural tendencies of some grape varieties for white wines in Moldavian vineyards, under the influence of climatic changes. Lucrări Științifice USAMV „Ion Ionescu de la Brad" Iași, Seria Horticultură, vol.56, nr. 2, 303 - 308

18. Sadras V.O., Moran M.A., Bonada M., 2013, Effects of elevated temperatures in grapevine. I. Berry sensory traits, Aust J Grape Wine R 19, 95-106

19. Tartian A.C., Colibaba C., Niculaua M., Nechita B.C., Zamfir C., Moroşanu A.M., Cotea V.V., 2015, Comparative Study of the Biotypes of Busuioaca de Bohotin Variety from Husi Vineyard, BulletinUASVM Horticulture 72(2), 418-423

20. Tonietto J., Carbonneau A., 2004, A multicriteria climatic classification system for grape-growing regions worldwide. Agricultural and Forest Meteorology, 124(1/2), 81 - 97

21. Vișan L., Dobrinoiu R.V., Tamba-Berehoiu R., 2017, Studies on chromatic characteristics variation of grapes and red wines depending on the variety and eco pedoclimatic conditions, Romanian Biotechnological Letters, 22:1233412339

22. (http://www.oiv.int/en/technical-standards-anddocuments/methods-of-analysis/compendium-ofinternational-methods-of-analysis-of-wines-and-musts) 